\title{
Variable phosphorus uptake rates and allocation across microbial groups in the oligotrophic Gulf of Mexico
}

\author{
Kimberly J. Popendorf ${ }^{1 *}$ and Solange Duhamel ${ }^{1}$
}

${ }^{1}$ Lamont-Doherty Earth Observatory, Division of Biology and Paleo Environment, Columbia University, Palisades, New York 10964, USA

*To whom correspondence should be addressed:

Lamont-Doherty Earth Observatory, Columbia University, 15 Marine Biology, 61 Route 9W -

P.O. Box 1000, Palisades, New York 10964, USA, Phone: 1-845-365-8774, Email:

kimdorf@ldeo.columbia.edu

Running title: Variable microbial phosphorus uptake rate and allocation
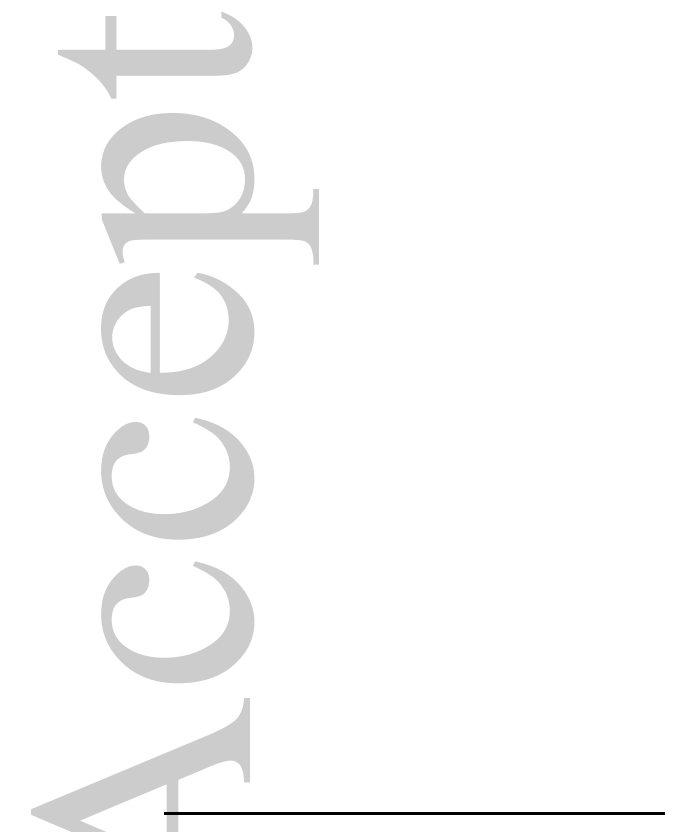

This article has been accepted for publication and undergone full peer review but has not been through the copyediting, typesetting, pagination and proofreading process, which may lead to differences between this version and the Version of Record. Please cite this article as doi: 10.1111/1462-2920.12932 


\section{Summary}

Microbial uptake of dissolved phosphorus $(\mathrm{P})$ is an important lever in controlling both microbial production and the fate and cycling of marine $\mathrm{P}$. We investigated the relative role of heterotrophic bacteria and phytoplankton in $\mathrm{P}$ cycling by measuring the $\mathrm{P}$ uptake rates of individual microbial groups (heterotrophic bacteria and the phytoplankton groups Synechococcus, Prochlorococcus, and picoeukaryotic phytoplankton) in the P-depleted Gulf of Mexico. Phosphorus uptake rates were measured using incubations with radiolabeled phosphate and adenosine triphosphate coupled with cell sorting flow cytometry. We found that heterotrophic bacteria were the dominant consumers of $\mathrm{P}$ on both a biomass basis and a population basis. Biovolume normalized heterotrophic bacteria $\mathrm{P}$ uptake rate per cell (amol $\mathrm{P}$ $\mu \mathrm{m}^{-3} \mathrm{hr}^{-1}$ ) was roughly an order of magnitude greater than phytoplankton uptake rates, and heterotrophic bacteria were responsible for generally greater than $50 \%$ of total picoplankton $\mathrm{P}$ uptake. We hypothesized that this variation in uptake rates reflects variation in cellular $\mathrm{P}$ allocation strategies, and found that, indeed, the fraction of cellular P uptake utilized for phospholipid production was significantly higher in heterotrophic bacteria compared to cyanobacterial phytoplankton. These findings indicate that heterotrophic bacteria have a uniquely P-oriented physiology and play a dominant role in cycling dissolved $\mathrm{P}$. 


\section{Introduction}

Microbial activity plays a central role in defining the flow of material through the surface ocean, regulating the chemical form and rate of transfer of material through this critical component of Earth systems. Phosphorus (P) is an essential element for all life, and the rate of microbial uptake of $\mathrm{P}$ is an important lever in controlling both the rate of microbial production and the fate and cycling of $\mathrm{P}$ in marine systems (Karl, 2014). Within the marine microbial community there is a wide array of metabolic functions (Giovannoni and Stingle, 2005;

Kujawinski, 2011). These diverse physiologies are reflected in variation in microbial nutrient uptake rates and affinities for different quantity and quality of substrates (Duhamel et al., 2007; Björkman et al., 2012; White et al., 2012; Lomas et al., 2014). By investigating the variation in microbial $\mathrm{P}$ uptake rates, we can provide insight into both the relative $\mathrm{P}$ needs of different microbial groups and the ecological role that these microbes are playing in the flux of $\mathrm{P}$ through the surface ocean.

Oligotrophic, P-depleted environments are critical biomes for defining the role of the ocean in the global carbon cycle, occupying large areas of the subtropical gyres (most notably the Sargasso Sea and southwest Pacific) as well as the Red and Mediterranean Seas (Krom et al., 1991; Li et al., 1998; Fuller et al., 2005; Moutin et al., 2005; Thingstad et al., 2005; Mather et al., 2008; Lomas et al., 2010). The offshore Gulf of Mexico is an oligotrophic environment where dissolved inorganic P (DIP) is exceedingly low in the surface ocean (Edwards et al., 2011) and is sometimes limiting for bacterial and phytoplankton production (Pomeroy et al., 1995; Turner and Rabalais, 2013). Cell-specific microbial P uptake rates have never been investigated in this 
region of the ocean, although they would provide useful insights into variation in microbial $\mathrm{P}$ dynamics in oligotrophic, P-depleted environments.

The pool of dissolved P that supports microbial activity is composed of both DIP and dissolved organic P (DOP), at ratios that vary widely across marine environments (Karl and Björkman, 2015). Studies thus far have indicated that phosphate $\left(\mathrm{PO}_{4}\right.$, the primary form of DIP) is bioavailable to and utilized by all marine microbes, though many microbes are also capable of utilizing DOP (Dyhrman et al., 2007). Understanding the relative uptake of these two forms of $P$ is of key importance for understanding the factors controlling microbial productivity, particularly in areas where $\mathrm{P}$ is at low concentrations and is potentially limiting microbial productivity.

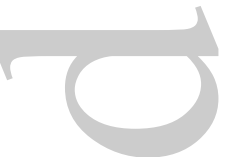

In the open ocean, the most abundant microbes, often by an order of magnitude, are small, non-pigmented heterotrophic bacteria (Azam et al., 1983; Ducklow, 2000; Jochem et al., 2004). Phytoplankton in oligotrophic open ocean environments are generally dominated by the small, unicellular cyanobacteria Prochlorococcus (Pro) and Synechococcus (Syn) (Li et al., 1983; Raven, 1998; Partensky et al., 1999). Flow cytometry with fluorescence activated cell sorting provides a powerful tool for differentiating these microbial groups within the mixed microbial community present in the environment (Lomas et al., 2011). By coupling cell sorting flow cytometry with isotope labeling it is possible to measure the cell-specific nutrient uptake rates in these distinct populations (Li, 1994; Zubkov et al., 2007; Casey et al., 2009; Michelou et al., 2011; Björkman et al., 2012; Lomas et al., 2014). These tools have been applied in several oligotrophic environments, but relatively few studies have investigated the uptake of both DIP 
and DOP, and none have extended these findings to determine rates of uptake into specific cellular biochemicals within environmental populations.

This study makes novel measurements of both microbial DIP and DOP uptake rates in individual microbial groups in the oligotrophic Gulf of Mexico, and investigates the intracellular factors that may contribute to the variation in microbial $\mathrm{P}$ uptake rates, providing new insight into the physiology and functioning of different microbial groups in the environment. We used cell sorting flow cytometry to determine the cellular rates of DIP and DOP uptake into heterotrophic bacteria, Pro, Syn, and the larger pigmented picoplankton (broadly grouped together as eukaryotic phytoplankton, euk). Our aim was to identify the major microbial players in P cycling in the Gulf of Mexico, and to investigate the relative importance of DIP and DOP uptake for each microbial group. To build a better mechanistic understanding of the factors leading to variation in $\mathrm{P}$ uptake rates, we investigated the variation in cellular allocation of $\mathrm{P}$ across these microbial groups. It has been found that phospholipid production can be responsible a large fraction of bulk microbial P uptake, up to 30\% (Van Mooy et al., 2006; Van Mooy et al., 2009), yet phospholipids represent a highly variable fraction of total particulate $\mathrm{P}(1-14 \%$, Popendorf et al., 2011b). Some phytoplankton can substitute non-P containing membrane lipids in place of phospholipids in P-deplete conditions, however heterotrophic bacterial membranes have been shown to be dominated by P-lipids in even P-depleted environments (Van Mooy et al., 2006; Van Mooy et al., 2009; Popendorf et al., 2011a). Thus we expect that lipids are likely to be one of the most variable intracellular biochemical P pools across microbial groups, and that this variation in $\mathrm{P}$ allocation to lipid production may be a major factor contributing to variation in $\mathrm{P}$ uptake rates in a P-depleted environment. We applied a novel combination of isotope labeling, 
cell sorting flow cytometry, and lipid purification to make the first direct measurement of $\mathrm{P}$ allocation into intracellular lipids in individual microbial groups.

\section{Results}

\section{Hydrographic conditions and nutrient concentrations}

Samples were collected at three stations in the offshore waters of the Northern Gulf of Mexico (exact locations given in Table 1). Samples were collected at $10 \mathrm{~m}$ depth and the deep chlorophyll maximum (DCM), which ranged from 50-60 m. At all three sites, salinity in the upper $60 \mathrm{~m}$ was above $36 \mathrm{PSU}$, indicating that the sites were not impacted by the Mississippi

River plume. Salinity and temperature did not vary substantially between sites (Table 1). At 10 m, DIP (measured as soluble reactive phosphorus, SRP) was at very low concentration, averaging $9 \pm 4 \mathrm{nM}$ across the three stations (range 5-12 nM; Fig. 1, Table 1). DOP concentration at $10 \mathrm{~m}$ was much higher and similarly consistent across stations, averaging $105 \pm$ $15 \mathrm{nM}$ (range 93-122 nM), and comprising approximately 93\% of the total dissolved P (TDP) pool on average. At the DCM, P concentrations were much more variable across the three stations. At stations 1 and 3, at the DCM, the DIP concentration was significantly elevated relative to $10 \mathrm{~m}$, and was similar to or greater than the DOP concentration (DOP comprising $55 \%$ and $35 \%$ of TDP at stations 1 and 3 respectively). In contrast, at station 2 the dissolved $\mathrm{P}$ concentrations at the DCM were similar to those at $10 \mathrm{~m}$, with DIP $<20 \mathrm{nM}$ at both depths and DOP concentration greater than $90 \%$ of TDP at both depths (DOP comprising $94 \%$ and $92 \%$ of TDP, at $10 \mathrm{~m}$ and the DCM respectively).

\section{Microbial populations}


The most abundant microbial group was non-pigmented heterotrophic bacteria (bac), averaging $1.2 \pm 0.3 \times 10^{5}$ cells $\mathrm{mL}^{-1}$ across all samples from all stations (Fig. 2A, B; Table 2). There was no statistical difference in abundance between samples from $10 \mathrm{~m}$ and the DCM (Fig. 2). Phytoplankton was dominated by small picoplankton groups, with the most abundant microbial groups being the cyanobacteria Pro and Syn. At both $10 \mathrm{~m}$ and the DCM Pro was nearly as abundant as $b a c$, while Syn was nearly an order of magnitude less abundant. Pro abundance was not significantly different at the DCM compared to $10 \mathrm{~m}$, while Syn abundance was higher at the DCM compared to $10 \mathrm{~m}$. At both depths, euk were less abundant than the cyanobacteria, at $10 \mathrm{~m}$ an order of magnitude less abundant than Syn, and at the DCM about half the abundance of Syn.

\section{Phosphorus uptake rates}

Phosphorus uptake rates were measured using incubations with either radiolabeled phosphate (orthophosphate, abbreviated ${ }^{33} \mathrm{PO}_{4}$ ), representing DIP, or radiolabeled adenosine triphosphate $\left({ }^{33} \mathrm{P}-\gamma\right.$-ATP), a DOP compound. DIP uptake rates were calculated using the uptake of ${ }^{33} \mathrm{PO}_{4}$ and the ambient DIP concentration, while the uptake of ${ }^{33} \mathrm{P}-\gamma$-ATP was used to estimate both uptake rates of ATP (Fig. 2; Table 2) and DOP (Table 2; calculation methods given in

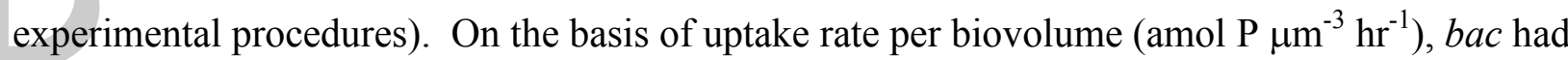
the highest $\mathrm{P}$ uptake rates in all samples (Fig. 2C, D). Bac P uptake rates exceeded those of the other microbial groups by more than an order of magnitude for ATP at both $10 \mathrm{~m}$ and the DCM as well as for DIP at $10 \mathrm{~m}$. Bac P uptake rates per biovolume were roughly four times or more those of other groups for DIP at the DCM (Fig. 2; Table 2). 
On a per cell basis (amol P cell ${ }^{-1} \mathrm{hr}^{-1}$ ), euk and Syn presented the highest DIP and ATP uptake rates at both depths (Fig. 2 E,F; Table 2). Euk uptake rates were greater than Syn for both substrates at both depths, though the difference was only significant for ATP uptake rates at 10 m (Fig. 2E; significant at $p<0.05$ ). Pro and bac had lower per cell $\mathrm{P}$ uptake rates for both substrates at both depths, less than half the euk uptake rate in most cases (Fig. 2E, F). Bac per cell P uptake rates were greater than Pro in all cases except for DIP uptake at the DCM, where $b a c$ had the lowest per cell uptake rates amongst the microbial groups (Fig. 2F). For $b a c$, DIP uptake rate was significantly higher at $10 \mathrm{~m}$ compared to the DCM (significant at $p<0.05$ ). For Syn and euk, DIP uptake rates were greater at the DCM compared to $10 \mathrm{~m}$. For Pro there was no significant difference in DIP uptake rates between $10 \mathrm{~m}$ and the DCM. For all microbial groups, ATP uptake rates were greater at $10 \mathrm{~m}$ compared to the DCM (difference was not significant for

\section{Pro).}

As a population, $b a c$ was responsible for $>60 \%$ of total picoplankton ATP uptake rate (pmol P L ${ }^{-1} \mathrm{hr}^{-1}$ ) at $10 \mathrm{~m}$ and the DCM, and $>50 \%$ of total picoplankton DIP uptake at $10 \mathrm{~m}$ and roughly $25 \%$ of DIP uptake at the DCM (Fig. 3). Pro was responsible for roughly $30 \%$ of total picoplankton DIP uptake at $10 \mathrm{~m}$ and $20 \%$ at the DCM, but was responsible for less than $10 \%$ of total picoplankton ATP uptake at both $10 \mathrm{~m}$ and the DCM. At the DCM euk was responsible for $>20 \%$ of DIP uptake and almost $15 \%$ of ATP uptake; but at $10 \mathrm{~m}$ euk represented $<10 \%$ of DIP and ATP uptake. Syn was responsible for roughly $20 \%$ of total picoplankton ATP uptake at both depths, and was responsible for roughly $40 \%$ and $10 \%$ of the total picoplankton DIP uptake at the DCM and $10 \mathrm{~m}$, respectively. 


\section{Phosphorus allocation into phospholipids}

The uptake rate of $\mathrm{P}$, from both ${ }^{33} \mathrm{PO}_{4}$ and ${ }^{33} \mathrm{P}-\gamma$-ATP, into specific phospholipid headgroup classes was measured in individual groups of microbes using cell sorting by flow cytometry followed by preparative liquid chromatography. The production rates (amol $\mathrm{P}$ cell ${ }^{-1}$ $\mathrm{hr}^{-1}$ ) of the phospholipids phosphatidylglycercol (PG), phosphatidylethanolamine (PE), and phosphatidylcholine (PC) were measured in Pro, Syn, and bac at $10 \mathrm{~m}$. These production rates were divided by the total cellular $\mathrm{P}$ uptake rates $\left(\right.$ amol $\mathrm{P}$ cell $\left.{ }^{-1} \mathrm{hr}^{-1}\right)$ to determine the percentage of $\mathrm{P}$ uptake allocated to phospholipid production in each microbial group (Fig. 4; Table 2). Bac allocated significantly more P uptake to phospholipid production,compared to Pro and Syn, for P from both DIP and ATP (significant at $p<0.05$ ). Notably, for all three microbial groups there was no statistical difference in the fraction of DIP uptake or ATP uptake allocated to phospholipid production ( $p>0.05$, paired $t$-test). Across both P substrates, bac allocated an average of $18.2 \pm 4.0 \%$ of P uptake to phospholipid production, while Pro and Syn allocated an average of $6.3 \pm 1.3 \%$ and $3.7 \pm 1.6 \%$ respectively.

1

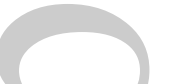

The vast majority of phospholipids produced by the cyanobacteria were PG, $81 \%$ of total phospholipids production for Pro and 85\% for Syn (averaged across incorporation of both DIP and ATP). In Pro and Syn there was some incorporation of P into PE (15\% and $11 \%$ of total phospholipid production for Pro and Syn, respectively) and minimal incorporation of P into PC (5\% and 4\% for Pro and Syn, respectively). In contrast, PE was a much larger fraction of phospholipids produced by bac, approximately $42 \%$, while PG was $50 \%$ and PC was $8 \%$ of total phospholipid production (averaged across incorporation of both DIP and ATP). 


\section{Discussion}

\section{Major microbial players in phosphorus cycling}

Due to both the high relative abundance of $b a c$ and their per cell uptake rates, as a population $b a c$ dominated total picoplankton $\mathrm{P}$ uptake. At both $10 \mathrm{~m}$ depth and the DCM, bac were responsible for the majority of picoplankton ATP uptake, as well as the majority of DIP uptake at $10 \mathrm{~m}$. This concurs with the results of prior studies examining cell specific $\mathrm{P}$ uptake rates in other regions that have found heterotrophic bacteria to be the primary agents of DIP and DOP uptake in the Sargasso Sea (Michelou et al., 2011), the central North Atlantic (Zubkov et al., 2007), DIP uptake in the Mediterranean Sea (DOP uptake not measured; Talarmin et al., 2014), and DOP uptake in the North Pacific subtropical gyre (Björkman et al., 2012).

Relative to their abundance, Pro played a small role in community P uptake, particularly for ATP. With low ATP uptake rates per cell, less than one-fifth the other microbial groups, Pro was responsible for less than one-tenth of the total picoplankton ATP uptake at both depths. The patterns of P uptake rates in Pro and bac that we observed in the Gulf of Mexico were similar to the patterns found in a study in the North Pacific subtropical gyre (Björkman et al., 2012). These findings support the evidence that Pro is particularly well-adapted for DIP uptake in low P environments (Lomas et al., 2014) and the hypothesis that Pro may thus rely relatively little on DOP uptake relative to other organisms (Martiny et al., 2009; Duhamel et al., 2010).

A more systematic trend in the distinct roles of the different microbial groups in $\mathrm{P}$ cycling is apparent when each group's contribution to total picoplankton P uptake is plotted against their contribution to total picoplankton cell abundance (Fig. 5A) and total picoplankton 
biovolume (Fig. 5B). Across all microbial groups, there was a positive trend in contribution to $\mathrm{P}$ uptake relative to cell abundance (Fig. 5A). The low contribution of Pro to community P uptake is particularly apparent relative to their cell abundance. In contrast, euk made a relatively high contribution to $\mathrm{P}$ uptake relative to their cell abundance (Fig. 5A), but a low contribution to $\mathrm{P}$ uptake relative to their biovolume (Fig. 5B). Syn also made a relatively high contribution to $\mathrm{P}$ uptake relative to their cell abundance (Fig. 5A), though there was not a strong relationship between their contribution to biovolume and $\mathrm{P}$ uptake (Fig. 5B). For $b a c$, their contribution to $\mathrm{P}$ uptake is roughly proportional to their cell abundance (Fig. 5A), however their contribution to $\mathrm{P}$ uptake is notably high relative to their biovolume (Fig. 5B).

The high $\mathrm{P}$ uptake rate per biovolume that we measured in $b a c$ is in accordance with the high relative $\mathrm{P}$ content that has been observed in bacteria. In bac from the P-deplete Sargasso Sea Gundersen et al. (2002) found relatively low C:P, in the range of 59-143, compared to a study of P-deplete cultures of cyanobacteria which had much higher C:P ratios on the order of 464-779 (Bertilsson et al., 2003). A study of cellular C and P quotas of Pro, Syn, and bac in environmental populations showed this same trend in high C:P in cyanobacteria relative to bac in the central North Atlantic (Grob et al., 2013).

The advances in cell sorting flow cytometry that have enabled the measurement of nutrient uptake rates in individual marine microbial groups from environmental samples are still relatively recent (Zubkov et al., 1999; Lebaron et al., 2001; Zubkov et al., 2001; Lebaron et al., 2002). The use of this tool is increasing rapidly (Lomas et al., 2011), and across studies a relatively coherent picture of microbial P function is emerging. The per cell P uptake rates that 
we measured for Pro, Syn, euk and bac in the Gulf of Mexico displayed similar patterns of variation across microbial groups and were numerically similar to measurements made in the Sargasso Sea (Casey et al. 2009; Michelou et al. 2011) and the western North Atlantic (Lomas et

al. 2014). Indeed our estimates of uptake rate per biovolume fall within the standard deviation of rates found in Casey et al. (2009), indicating that these microbial groups may function similarly across P-depleted environments. Our results concur with those of other studies demonstrating that $b a c$ have distinctly high $\mathrm{P}$ uptake rates per biovolume, and are playing a dominant role in phosphorus cycling.

\section{Comparison of DIP versus DOP uptake across microbial groups}

The relative microbial reliance on DIP versus DOP as a P substrate is a central question in understanding the nutrient controls on microbial productivity and the microbial role in $\mathrm{P}$ cycling. In many ocean biomes the concentration of DOP far exceeds DIP (Karl and Björkman, 2015). The ratio of DOP:DIP that we observed at $10 \mathrm{~m}$, roughly 9:1, was very similar to ratios observed in the surface waters of the Sargasso Sea (Lomas et al., 2010) and the North Pacific Subtropical Gyre (Björkman et al., 2000; 2012). Given the high concentration of DOP relative to DIP, this pool has the potential to supply a large fraction of microbial P needs, dependent upon the composition and lability of the DOP pool and on the microbial capacity to utilize and remineralize these substrates in a particular environment (Lomas et al., 2010; White et al., 2012). Despite the fundamental nature of this question, the tools available to quantitatively assess microbial DOP uptake are relatively limited.

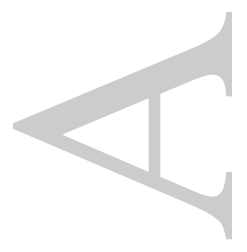


Phosphate represents the majority of the DIP pool (Benitez-Nelson, 2000), therefore the uptake of ${ }^{33} \mathrm{PO}_{4}$ can be assumed to be directly representative of DIP uptake. DOP, on the other hand, is a pool of chemically diverse compounds, the uptake of which is unlikely to be accurately represented by any single compound. When described by bond-class, the pool of DOP has been found to be roughly $75 \%$ phosphoesters across a range of environments, and this bond-class of compounds is expected to represent the more bioavailable fraction of DOP (Clark et al., 1998, 1999; Kolowith et al., 2001; Young and Ingall, 2010). Dissolved ATP is expected to be $<0.5 \%$ of total DOP (Karl and Bossard, 1985; Björkman and Karl, 2001, 2005), however, as a phosphoester compound, ATP may be considered to be representative of phosphoester DOP uptake. Therefore we used the measured uptake rate of ${ }^{33} \mathrm{P}-\gamma$-ATP two different ways: (1) to represent ATP uptake rate, providing a lower bound, conservative estimate of uptake of one compound of DOP; and (2) to represent phosphoester DOP uptake, providing an estimate of uptake of this broader, presumably bioavailable pool of DOP (Table 2). If we assume that the uptake of ${ }^{33} \mathrm{P}-\gamma$-ATP is quantitatively representative of phosphoester DOP uptake, then the rates that we measured indicate that DOP uptake could be supplying the majority of P needs for each microbial group, roughly $80 \%$ for Syn, euk, and bac, and close to $60 \%$ for Pro (Table 2). However, due to the uncertainty in the fraction of the DOP pool represented by ATP uptake true proportions are likely to be far lower.

Though tracing the uptake of one organic $\mathrm{P}$ compound (here ${ }^{33} \mathrm{P}-\gamma$-ATP) is an imperfect method for quantifying the uptake of the chemically diverse DOP compounds, we can nonetheless gain insight on the relative reliance of each group on DOP by comparing the ratio of DIP uptake rate to DOP uptake rate (hereafter, DIP:DOP rate) across the different microbial 
groups (Fig. 6). Due to the uncertainty in the measurement of DOP uptake rates these ratios do not represent the actual proportion of cellular P coming from DOP versus DIP. However, by comparing DIP:DOP rate across microbial groups we can identify distinct relative trends in preferential P substrate utilization. At $10 \mathrm{~m}$ Pro had a high DIP:DOP rate relative to the other microbial groups, indicating that Pro utilizes relatively more DIP versus DOP compared to the other groups. Euk, on the other hand, had a DIP:DOP rate less than half that of Syn and bac, indicating relatively high utilization of DOP versus DIP compared to the other groups. At the DCM, the DIP:DOP for $b a c$ was much lower than other groups, indicating that at the DCM $b a c$ utilized relatively more DOP versus DIP compared to the other groups

\section{High rates of $P$ uptake reflect different $P$ allocation by heterotrophic bacteria}

Per unit biomass, $b a c$ had much higher $\mathrm{P}$ uptake rates than other picoplankton groups.

This high cellular uptake may be directed towards many different cellular materials that require P. The most abundant of these intracellular P-containing biochemicals are nucleic acids, both DNA (Bertilsson et al., 2003; Giovannoni et al., 2005; Coleman and Chisholm, 2010;

Zimmerman et al., 2014b) and RNA (Karl, 1981; Kemp et al., 1993; Kerkhof and Ward, 1993; Van Mooy and Devol, 2008; Zimmerman et al., 2014a), lipids (Wakeham et al., 1997; Van Mooy et al., 2009; Popendorf et al., 2011b), potentially P storage compounds such as polyphosphate (Perry, 1976; Diaz et al., 2008; Martin and Van Mooy, 2013), and to a lesser but physiologically important extent energy trafficking molecules such as ATP and NADH (Bossard and Karl, 1986). We hypothesize that the observed variation in $\mathrm{P}$ uptake rate per biomass across microbial groups is driven in part by variation in P allocation into different biochemicals. Under this hypothesis, $b a c$ would allocate the "excess" $\mathrm{P}$ from their high uptake rates into certain 
biochemicals rather than having uniformly more abundant P-containing biochemicals (per biovolume) relative to phytoplankton.

Based on evidence of variation in microbial membrane lipid composition (Van Mooy et

al., 2006; Popendorf et al., 2011a) we targeted lipids as a biochemical likely to be playing an important role in the variation in $\mathrm{P}$ uptake rates across microbial groups. It has previously been demonstrated that many phytoplankton are capable of substituting non-P lipids in place of phospholipids in low P conditions (Benning et al., 1993; Benning et al., 1995; Van Mooy et al., 2006; Van Mooy et al., 2009; Popendorf et al., 2011a), bringing their cellular phospholipid content to less than $10 \%$ relative to total lipids. In contrast, bac maintain a minimum of $60 \%$ phospholipids relative to total cellular intact polar lipids even in P-deplete conditions (Popendorf

et al., 2011a). Presumably this ability to decrease cellular phospholipid content conveys an advantage to cells through a decreased cellular $\mathrm{P}$ quota or the ability to redirect $\mathrm{P}$ towards other biochemical pools, in either case altering the allocation of $\mathrm{P}$ within the cells. To date no study had directly measured this allocation in individual microbial groups in the environment.

In the oligotrophic, P-deplete Gulf of Mexico, we found significant variation in P allocation to phospholipids across three different microbial groups, ranging from 4 to $20 \%$ of $\mathrm{P}$ uptake allocated to phospholipid production. We found that bac allocated a relatively large fraction of $\mathrm{P}$ uptake to phospholipids, roughly $18 \%$, while cyanobacterial phytoplankton, Pro and Syn, allocated far less P to phospholipids, roughly 5\%. In prior measurements of bulk planktonic community P uptake allocation to phospholipid production, Van Mooy et al. (2006, 2009) observed a range of allocation from 1 to $28 \%$, but this wide-range in variation only 
occurred across environments that spanned roughly two orders of magnitude of DIP

concentrations. Our data indicates that within a narrow range of P-depleted DIP concentrations, in a single biome, $b a c$ and phytoplankton are employing distinct $\mathrm{P}$ allocation strategies that lead

to large variation in $\mathrm{P}$ allocation to lipids. This demonstrates that lipids are a variable fraction of cellular $\mathrm{P}$ across microbial groups, leading to variation in the biochemical form of intracellular $\mathrm{P}$ across microbial groups.

Given that lipids form the membranes of cells, we might expect that the fraction of cellular material devoted to lipid production would scale with the increasing surface area to volume ratio as cell size decreases. We explored this relationship to determine if the observed variation in allocation could be accounted for by variation in cell size. Assuming average cell diameters and spherical geometry, we found that across the three microbial groups there was a positive trend in the relationship between expected surface area to volume ratio and fraction of $\mathrm{P}$ allocated to phospholipid production (Fig. 4C). Normalized to the expected surface area to volume ratio, the P allocation to phospholipids was significantly greater in bac than in Pro and Syn (Fig. 4D, $p<0.05$ with one-way ANOVA and post-hoc Tukey-Kramer hsd test). This indicates that, disproportionate with their higher surface area to volume ratio, $b a c$ are allocating a larger fraction of cellular $\mathrm{P}$ uptake to the production of phospholipids relative to other cellular components. This high allocation into phospholipids is likely a factor driving the higher per volume P uptake rates in $b a c$ relative to other microbial groups.

Variation in phospholipid headgroup classes produced by heterotrophic bacteria and cyanobacteria 
Exploring the classes of phospholipids produced by each microbial group displayed differences in microbial physiology across the groups and indicated dominant microbial sources for specific phospholipid classes. The phospholipids produced by Pro and Syn were predominately PG, which concurs with the lipid profile observed in both cultures of Pro and Syn (Wada and Murata, 1998; Van Mooy et al., 2006) and environmental samples (Popendorf et al., 2011a). Pro and Syn produced some PE and also a small amount of PC, which concurs with analysis of environmental samples (Popendorf et al., 2011a) but is at odds with data from axenic cultures (Wada and Murata 1998; Van Mooy et al. 2006). It has previously been suggested that some of the PE and PC found in flow cytometry cell sorted environmental samples may be due to minor contributions from robust cyanobacteria-heterotrophic bacteria cell assemblages (Malfatti and Azam, 2009) which are potentially not dissociated during the sorting process (Popendorf et al., 2011a). Alternatively, it may be that the differences observed between axenic cultures and environmental populations reflect differences in physiology when cells are in a natural setting exposed to predation, competition, and other factors, or there may be different strains present in the environment than those that have been examined in culture. In either scenario, the contribution of cyanobacteria to the production of PE and PC appears to be relatively minimal, and PG was the primary phospholipid produced by both Pro and Syn.

In the sorted population of $b a c$, there was more production of $\mathrm{PE}$ and $\mathrm{PC}$ relative to phytoplankton, with roughly even proportions of PG and PE produced and a small amount of PC. The proportions of phospholipids produced were similar to the phospholipid profile observed in environmental samples of heterotrophic bacteria (Popendorf et al 2011). As with the phytoplankton, this was slightly different from the lipid profile found in cultures of heterotrophic 
bacteria where PE and PG have been found to be dominant but PC is minimal or not present

(Oliver and Colwell, 1973; Van Mooy et al., 2009). This again may be a reflection of variation in strains present in the environment compared to culture, or different physiology in an environmental setting. From our measurements of phospholipid production in these different cell groups, in conjunction with evidence from both cultures and other environmental studies, it is clear that $b a c$ produce significantly more PE than cyanobacteria. Both PE and PC are zwitterionic molecules, at seawater $\mathrm{pH}$, while PG is negatively charged (Van Mooy and Fredricks, 2010). Therefore this difference in phospholipid composition between bac and cyanobacteria likely leads to differences in the physiological properties of the cell membranes (Zhang and Rock, 2008).

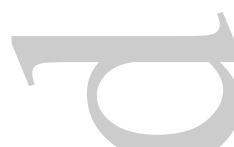

\section{Conclusion}

In the oligotrophic P-depleted Gulf of Mexico we found that bac are playing a dominant role in microbial P uptake, both as DIP and ATP. The contribution of bac to total picoplankton P uptake is disproportionately high relative to their contribution to total picoplankton biovolume.

Pro was found to rely relatively less on DOP uptake compared to the other microbial groups, and had low contribution to total picoplankton P uptake relative to their cell abundance.

Cyanobacterial phytoplankton, both Pro and Syn, were found to allocate significantly less of their cellular P uptake to phospholipid production, compared to bac which allocated roughly onefifth of total P uptake to phospholipid production. With high P uptake rates per biomass, high allocation of $\mathrm{P}$ to phospholipids, and a dominant role in microbial P uptake, heterotrophic 
bacteria have a uniquely P-oriented physiology and are playing a significant role in the cycling of $\mathrm{P}$ in P-depleted environments.

\section{Experimental Procedures}

\section{Shipboard sample collection}

Samples were collected at three sites in the Gulf of Mexico in April 2013 during the WS1304 cruise aboard the $R / V F$. G. Walton Smith. Whole seawater samples were collected at $10 \mathrm{~m}$ depth and at the deep chlorophyll maximum (DCM, determined on the downcast using a rosette-mounted fluorometer; depths and exact locations given in Table 1) using Niskin bottles mounted on a rosette equipped with a conductivity, temperature and depth sensor package (Seabird) as well as a fluorometer, photosynthetically active radiation (PAR) and oxygen sensors. All samples were collected at the same time of day just before dawn. Upon arrival on deck, water for cell enumeration and incubations was collected into acid-clean, $2 \mathrm{~L}$ polycarbonate bottles, while water for nutrient analysis was collected into acid-clean highdensity polyethylene bottles (HDPE) and immediately frozen $\left(-20^{\circ} \mathrm{C}\right)$.

\section{Dissolved phosphorus analysis}

Frozen samples (duplicate, $220 \mathrm{~mL}$ ) were kept at $-20{ }^{\circ} \mathrm{C}$ until analysis in the lab. Soluble reactive phosphorus (SRP) was analyzed in triplicate $50 \mathrm{~mL}$ samples using the magnesium induced co-precipitation (MAGIC) method (Karl and Tien, 1992) with arsenate correction (Johnson, 1971) and molybdenum blue complex spectrophotometric analysis (Strickland and Parsons, 1972) as described by Lomas et. al (2010). Samples were read on a Shimadzu UV-Vis 2450 spectrophotometer, at $880 \mathrm{~nm}$ in a $10 \mathrm{~cm}$ quartz cuvette (Starna). The limit of detection 
and precision were $5.1 \mathrm{nM}$ and $2.3 \mathrm{nM}$, respectively (standard deviation of triplicate

measurements). Total dissolved phosphorus (TDP) was analyzed using potassium persulfate digestion according to Thomson-Bulldis and Karl (1998). Briefly, potassium persulfate was added to triplicate $40 \mathrm{~mL}$ seawater samples (final concentration $0.03 \mathrm{M}$ ) in glass screw-top centrifuge vials with Teflon-lined caps. Samples were autoclaved at $121{ }^{\circ} \mathrm{C}$ for 30 minutes. Following acid digestion, SRP concentration was analyzed as described above. Standards were prepared in artificial seawater using both potassium phosphate monobasic and glycerophosphate to check recovery. Glycerophosphate recovery relative to phosphate was greater than $95 \%$. Dissolved organic phosphorus (DOP) was calculated as the difference between TDP and SRP, and standard deviations (Table 1) were propagated accordingly.

\section{Cell enumeration}

Duplicate $1.5 \mathrm{~mL}$ samples were preserved in electron microscopy grade

paraformaldehyde (PFA) solution ( $0.5 \%$ final concentration) for $15-30$ minutes at room temperature, flash frozen in liquid nitrogen and stored at $-80{ }^{\circ} \mathrm{C}$ until analysis in the lab. Cells were analyzed using a BD Influx flow cytometer equipped with a fluorescence activated sort module, following the procedure outlined in Björkman et al. (2012). Sheath fluid was BioSure sheath solution diluted 10 fold with $18.2 \Omega$ ultrapure water and filtered through a $0.2 \mu \mathrm{m}$ capsule filter in-line on the instrument fluidic system. Pigmented phytoplankton were enumerated without staining using excitation by 488 and $457 \mathrm{~nm}$ lasers focused through the same pinhole, improving differentiation of relatively low autofluorescent populations of Prochlorococcus (Björkman et al. 2012; Duhamel et al. 2014). Picoeukaryotic pigmented phytoplankton (euk), Synechococcus (Syn) and Prochlorococcus (Pro) populations were discriminated by chlorophyll 
fluorescence (Chl; 692/40 nm) and forward scatter (FSC). Syn high phycoerythrin fluorescence

(PE; 585/40 nm) enabled discriminating them from Pro and euk. Non-pigmented picoplankton were enumerated in samples stained with SYBR Green I nucleic acid stain $(0.01 \%$ final concentration; Lonza) and excited by 488 and $405 \mathrm{~nm}$ lasers focused through the same pinhole, which improves discrimination of Pro from non-pigmented heterotrophic bacteria (bac) by SYBR fluorescence (Green; 520/15 nm) as well as FSC and Chl. However when Pro and bac overlapped (mostly in surface unconcentrated samples), the whole SYBR-stained picoplankton group, excluding Syn and euk but including both Pro and bac, was counted and bac cell $\mathrm{mL}^{-1}$ were quantified by subtracting Pro cell $\mathrm{mL}^{-1}$ enumerated in unstained samples (Björkman et al., 2012).

\section{Incubations with ${ }^{33} P$ labeled substrates}

Incubations were conducted with additions of either ${ }^{33} \mathrm{P}$ labeled phosphate

(orthophosphoric acid, ${ }^{33} \mathrm{PO}_{4}$; Perkin Elmer product \#NEZ080 001MC) or ${ }^{33} \mathrm{P}$-labeled adenosine triphosphate (adenosine 5'-triphosphate $\left[\gamma-{ }^{33} \mathrm{P}\right],{ }^{33} \mathrm{P}-\gamma$-ATP; Perkin Elmer product \#NEG302H 250UC). Incubations were conducted in acid-cleaned polycarbonate bottles, either $72 \mathrm{~mL}$ whole seawater with $2.6 \times 10^{3} \mathrm{~Bq} \mathrm{~mL}^{-1}{ }^{33} \mathrm{P}$ additions, or $155 \mathrm{~mL}$ with $4.8 \times 10^{3} \mathrm{~Bq} \mathrm{~mL}^{-1}{ }^{33} \mathrm{P}$ additions. Following addition of ${ }^{33} \mathrm{P}$, bottles were placed in on-deck flow-through incubators at approximately surface temperature conditions and depth-representative light conditions.

Samples were incubated for 3-8 hours according to expected DIP turnover time (determined by shipboard measurements). Killed controls, fixed with PFA (1\% final concentration) prior to ${ }^{33} \mathrm{P}$ addition, were processed along with the samples. At the end of incubations, bottles were split into the following subsamples: for cell-specific P uptake rate, duplicate $3.5 \mathrm{~mL}$ samples were 
fixed with PFA ( $0.5 \%$ final concentration) and frozen as described above; for dissolved phosphorus turnover time, $10 \mathrm{~mL}$ was filtered onto a $25 \mathrm{~mm} 0.2 \mu \mathrm{m}$ polycarbonate filter (Millipore) and measured shipboard on a liquid scintillation counter (Beckman Coulter); and, from the $155 \mathrm{~mL}$ incubations only, $88 \mathrm{~mL}$ was concentrated for cell-specific phospholipid production rate measurement as described below.

\section{Cell-specific P uptake rate}

The microbial groups Pro, Syn, euk, and SYBR-stained picoplankton (excluding Syn and euk) were discriminated as described above for cell enumeration and were sorted at an average sort rate of approximately 30-200 cell s ${ }^{-1}$ with settings optimized for sort purity. Sorting accuracy was verified by sorting fluorescent polystyrene beads $(1 \mu \mathrm{m}$, Fluorescbrite beads plain YG, Polysciences Inc.) and counting them by epifluorescence microscopy. For each sample, approximately $5 \times 10^{4}, 2 \times 10^{4}, 2-10 \times 10^{3}$, and $1 \times 10^{5}$ cells were collected for Pro, Syn, euk, and SYBR-stained picoplankton, respectively. Fluorescent beads added to samples were also sorted (approximately $1.5 \times 10^{4}$ beads per sample) into separate tubes to assess background radioactivity (Björkman et al., 2012; Duhamel et al., 2014). Sorts were collected directly into $6 \mathrm{~mL}$ polypropylene screw-cap scintillation vials, to which $4 \mathrm{~mL}$ Ultima Gold LLT scintillation cocktail (Perkin Elmer) was added and samples shaken vigorously. Sample radioactivity was measured on a Perkin Elmer Tricarb 3110 TR liquid scintillation counter with low level option, 5 minute count time in the energy range 4-250 kEV. Activity of bac was determined by correcting for the contribution of Pro to the SYBR-stained activity as described for cell counts. For each sample, per cell P uptake rate was determined as follows:

$$
\mathrm{P}_{\mathrm{i}}=(\mathrm{A} / \mathrm{S}) * 1 /(\mathrm{t} * \mathrm{n})
$$


where $\mathrm{P}_{\mathrm{i}}$ is the microbial group-specific cellular $\mathrm{P}$ uptake rate $\left(\operatorname{amol} \mathrm{P}\right.$ cell-1 $\left.\mathrm{hr}^{-1}\right), \mathrm{A}$ is the ${ }^{33} \mathrm{P}$ activity in the flow-cytometry sorted cells (dpm), $\mathrm{S}$ is the specific activity of the ${ }^{33} \mathrm{P}$ in the seawater incubation $\left(\mathrm{dpm} \mathrm{mol}{ }^{-1} \mathrm{P}\right), \mathrm{t}$ is the length of the incubation $(\mathrm{hr})$, and $\mathrm{n}$ is the number of cells collected by cell sorting flow cytometry. To convert our measurement of ${ }^{33} \mathrm{PO}_{4}$ uptake rate into DIP uptake, we calculated the specific activity of $\mathrm{PO}_{4}$ as the ratio of the ${ }^{33} \mathrm{PO}_{4}$ spike to the measured concentration of ambient SRP. We used the measured uptake rate of ${ }^{33} \mathrm{P}-\gamma$-ATP two different ways: (1) to estimate the uptake rate of ATP, by calculating the specific activity of ${ }^{33} \mathrm{P}$ $\gamma$-ATP using the expected concentration of dissolved ATP from the literature, assumed to be 0.2 nM (Björkman and Karl, 2005); (2) to estimate the uptake rate of phosphoester DOP, by calculating the specific activity of ${ }^{33} \mathrm{P}-\gamma$-ATP using the measured DOP concentration, scaled for the $75 \%$ of DOP expected to be phosphoesters (Kolowith et al., 2001). Phosphorus uptake rate per volume was calculated by dividing the per cell uptake rates (Eq. 1) by the expected cell volume, assuming spherical cell geometry and the following cell diameters: bac $0.3 \mu \mathrm{m}$ (cell volume from Rappé et al., 2002, based on spherical geometry), Pro $0.6 \mu \mathrm{m}$ (Raven, 1998), Syn

$0.9 \mu \mathrm{m}$ (Raven, 1998), and euk $2.3 \mu \mathrm{m}$ (cell volume from Campbell et al., 1997, based on spherical geometry). Total picoplankton P uptake rate (amol $\mathrm{P} \mathrm{L}^{-1} \mathrm{hr}^{-1}$, Fig. 3) was calculated as the sum of each microbial group cell concentration $\left(\right.$ cell $\mathrm{mL}^{-1}$ ) multiplied by per cell $\mathrm{P}$ uptake rate $\left(\mathrm{amol} \mathrm{P} \operatorname{cell}^{-1} \mathrm{hr}^{-1}\right)$.

\section{Cell-specific phospholipid production rate}

Samples for cell-specific phospholipid production were concentrated at sea using gentle vacuum filtration similar to the method described by Popendorf et al. (2011) and Fawcett et al. (2011). Briefly, sample ( $88 \mathrm{~mL}$ ) was filtered through a $25 \mathrm{~mm} 0.2 \mu \mathrm{m}$ polycarbonate filter (Millipore), 
and filtration was stopped when less than $1 \mathrm{~mL}$ of liquid remained on filter. The liquid was transferred to a $2 \mathrm{~mL}$ cryovial with a pipette, and forceps were used to carefully transfer the wet filter to the cryovial (with the cell-side of the filter towards the interior of the vial). Filtered seawater with PFA ( $0.2 \mu \mathrm{m}$ filtered; $0.5 \%$ final concentration) was immediately added to the vial to a final volume of approximately $2 \mathrm{~mL}$. The vial was gently mixed and left at room temperature for 15-30 minutes. Samples were then flash frozen in liquid nitrogen and stored at $80^{\circ} \mathrm{C}$ until analysis in lab. Microbial populations were discriminated and sorted as described above for P uptake rate, with the exception of heterotrophic bacteria. For phospholipid production rate measurement it was necessary to separate SYBR-stained bac from SYBR-stained Pro (as opposed to the back-calculation of relative contribution of each group that is possible for per cell $\mathrm{P}$ uptake rate measurements). Using excitation with the 488 and 405 lasers in the same pinhole, on concentrated samples, it was possible to distinguish two distinct populations in Chl vs. FSC and Green vs. FSC, with $b a c$ having the lower FSC, Chl and Green signals. These two populations were sorted separately, and the phospholipid production rate of the higher FSC and fluorescence group was indistinguishable from the production rate of Pro measured in unstained samples (data not shown), confirming accurate differentiation of Pro and bac in the SYBR stained sorts. For each sample, approximately $8 \times 10^{5}, 7 \times 10^{5}$, and $7 \times 10^{5}$ cells were collected for Pro, Syn, and bac, respectively. Cells were collected for $e u k$ as well but cell abundance was too low for phospholipid production rate to be measured in this group. Cells were sorted directly into combusted ( $>4$ hours $\left.450{ }^{\circ} \mathrm{C}\right) 12 \mathrm{~mL}$ glass centrifuge vials. Immediately after sorting, lipids were extracted using a modified Bligh and Dyer solvent extraction protocol following Van Mooy and Fredricks (2010). Following methods described by Van Mooy et al. (2014), three phospholipid headgroup classes of intact polar diacylglycerolipids were then purified from the 
total lipid extract (TLE) using preparative high-pressure liquid chromatography (HPLC):

phosphatidylglycerol (PG), phosphatidylethanolamine (PE), and phosphatidylcholine (PC).

Separation and collection of purified fractions was carried out using an Agilent HP1050 HPLC

coupled with a Teledyne ISCO Foxy Jr. fraction collector and normal phase chromatography

with a PrincetonSpher diol column (100 Å poresize, $5 \mu \mathrm{m}$ silica beads, $150 \mathrm{~mm} \times 2.1 \mathrm{~mm})$. Full chromatography methods are given in Popendorf et al. (2013). Time-based fraction collection windows were set after verifying retention time and chromatographic stability using repeat injections of dipalmitoyl synthetic standards of PG, PE, and PC (Avanti Polar Lipids, Inc.) and detection with a Sedere Sedex 75 Evaporative Light Scattering Detector (ELSD). Retention time of standards was monitored every 7-10 samples to verify chromatographic stability. Following fraction collection, each fraction (1-2 mL HPLC eluents) was transferred to a $20 \mathrm{~mL}$ glass scintillation vial with $10 \mathrm{~mL}$ Ultima Gold LLT scintillation cocktail. Radioactivity of each phospholipid class was assayed on a liquid scintillation counter as described above.

\section{Statistical analysis}

Error in measurements $( \pm)$ are reported as the standard deviation of replicate measurements. Statistical significance of results was evaluated using statistics functions in Matlab (R2012a). Significance of differences between stations (Table 2) was tested using Kruskal-Wallis nonparametric analysis of variance and post-hoc Bonferroni test. Statistical differences reported between microbial groups used one-way ANOVA (normal distributions verified using the Lilliefors test) and post-hoc Tukey-Kramer test. Differences between depths and between DIP and ATP uptake used paired t-tests. Differences were considered significant at $p<0.05$. 


\section{Acknowledgements}

We thank Krista Longnecker for the opportunity to participate in the WS1304 cruise and for cruise support. We thank chief scientist Malinda Sutor and her labgroup for their assistance at sea, and thank the captain and crew of the R/V Walton Smith. We are grateful to Ben Van Mooy for the loan of the preparative HPLC system, enabling the lipid analysis work. We gratefully acknowledge funding support from the Gulf of Mexico Research Initiative (BP GRI Round 3/386 award to Sutor, Longnecker, Benfield, Maiti and Overton), and support from the NSF Chemical and Biological Oceanography Programs through award OCE-1434914 (to Popendorf and Duhamel).

\section{References}

Azam, F., Fenchel, T., Field, J.G., Gray, J.S., Meyer-Reil, L.A., and Thingstad, F. (1983) The Ecologocial Role of Water-Column Microbes in the Sea. Marine Ecology Progress Series 10: 257-263.

Benitez-Nelson, C.R. (2000) The biogeochemical cycling of phosphorus in marine systems. Earth-Science Reviews 51: 109-135.

Benning, C., Huang, Z.-H., and Gage, D.A. (1995) Accumulation of a Novel Glycolipid and a Betaine Lipid in Cells of Rhodobacter sphaeroides Grown under Phosphate Limitation. Archives of Biochemistry and Biophysics 317: 103-111.

Benning, C., Beatty, J.T., Prince, R.C., and Somerville, C.R. (1993) The sulfolipid sulfoquinovosyldiacylglycerol is not required for photosynthetic electron transport in Rhodobacter sphaeroides but enhances growth under phosphate limitation. Proceedings of the National Academy of Sciences 90: 1561-1565.

Bertilsson, S., Berglund, O., Karl, D.M., and Chisholm, S.W. (2003) Elemental composition of marine Prochlorococcus and Synechococcus: Implications for the ecological stoichiometry of the sea. Limnology and Oceanography 48: 1721-1731.

Björkman, K., and Karl, D.M. (2001) A novel method for the measurement of dissolved adenosine and guanosine triphosphate in aquatic habitats: applications to marine microbial ecology. Journal of Microbiological Methods 47: 159-167. 
Björkman, K., and Karl, D.M. (2005) Presence of dissolved nucleotides in the North Pacific Subtropical Gyre and their role in cycling of dissolved organic phosphorus. Aquatic Microbial Ecology 39: 193-203.

Björkman, K., Thomson-Bulldis, A.L., and Karl, D.M. (2000) Phosphorus dynamics in the North Pacific subtropical gyre. Aquatic Microbial Ecology 22: 185-198.

Björkman, K., Duhamel, S., and Karl, D.M. (2012) Microbial group specific uptake kinetics of inorganic phosphate and adenosine-5'-triphosphate (ATP) in the North Pacific Subtropical Gyre. Frontiers in Microbiology 3: 1-17.

Bossard, P., and Karl, D.M. (1986) The direct measurement of ATP and adenine nucleotide pool turnover in microorganisms: a new method for environmental assessment of metabolims, energy flux and phosphorus dynamics. Journal of Plankton Research 8: 1-13.

Campbell, L., Liu, H., Nolla, H.A., and Vaulot, D. (1997) Annual variability of phytoplankton and bacteria in the subtropical North Pacific Ocean at Station ALOHA during the 1991-1994 ENSO event. Deep-Sea Research I 44: 167-192.

Casey, J.R., Lomas, M.W., Michelou, V.K., Dyhrman, S.T., Orchard, E.D., Ammerman, J.W., and Sylvan, J.B. (2009) Phytoplankton taxon-specific orthophosphate (Pi) and ATP utilization in the western subtropical North Atlantic. Aquatic Microbial Ecology 58: 31-44.

Clark, L.L., Ingall, E.D., and Benner, R. (1998) Marine phosphorus is selectively remineralized. Nature 393: 426.

Clark, L.L., Ingall, E.D., and Benner, R. (1999) Marine organic phosphorus cycling: novel insights from nuclear magnetic resonance. American Journal of Science 2999: 724-737.

Coleman, M.L., and Chisholm, S.W. (2010) Ecosystem-specific selection pressures revealed through comparative population genomics. Proceedings of the National Academy of Sciences 107: 18634-18639.

Diaz, J., Ingall, E.D., Benitez-Nelson, C.R., Paterson, D., de Jonge, M.D., McNulty, I., and Brandes, J.A. (2008) Marine polyphosphate: a key player in geologic phosphorus sequestration. Science 320: 652-655.

Ducklow, H. (2000) Bacterial Production and Biomass in the Oceans. In Microbial Ecology of the Oceans. Kirchman, D.L. (ed). New York: Wiley-Liss, pp. 85-120.

Duhamel, S., Dyhrman, S.T., and Karl, D.M. (2010) Alkaline phosphatase activity and regulation in the North Pacific Subtropical Gyre. Limnology and Oceanography 55: 1414-1425.

Duhamel, S., Björkman, K., Doggett, J.K., and Karl, D.M. (2014) Microbial response to enhanced phosphorus cycling in the North Pacific Subtropical Gyre. Marine Ecology Progress Series. 
Duhamel, S., Moutin, T., Van Wambeke, F., Van Mooy, B.A.S., Rimmelin, P., Raimbault, P., and Claustre, H. (2007) Growth and specific P-uptake rates of bacterial and phytoplanktonic communities in the Southeast Pacific (BIOSOPE cruise). Biogeosciences 4: 941-956.

Dyhrman, S.T., Ammerman, J.W., and Van Mooy, B.A.S. (2007) Microbes and the marine phosphorus cycle. Oceanography 20: 110-116.

Edwards, B.R., Reddy, C.M., Camilli, R., Carmichael, C.A., Longnecker, K., and Van Mooy, B.A.S. (2011) Rapid microbial respiration of oil from the Deepwater Horizon spill in offshore surface waters of the Gulf of Mexico. Environmental Research Letters 6.

Fawcett, S.E., Lomas, M.W., Casey, J.R., Ward, B.B., and Sigman, D.M. (2011) Assimilation of upwelled nitrate by small eukaryotes in the Sargasso Sea. Nature geoscience 4: 717-722.

Fuller, N.J., West, N.J., Marie, D., Yallop, M., Rivlin, T., Post, A.F., and Scanlan, D.J. (2005) Dynamics of community structure and phosphate status of picocyanobacterial populations in the Gulf of Aqaba, Red Sea. Limnology and Oceanography 50: 363-375.

Giovannoni, S.J., and Stingle, U. (2005) Molecular diversity and ecology of microbial plankton. Nature 437: 343-348.

Giovannoni, S.J., Tripp, H.J., Givan, S., Podar, M., Vergin, K.L., Baptista, D. et al. (2005)

Genome streamlining in a cosmopolitan oceanic bacterium. Science 309: 1242-1245.

Grob, C., Ostrowski, M., Holland, R.J., Heldal, M., Norland, S., Erichsen, E.S. et al. (2013) Elemental composition of natural populations of key microbial groups in Atlantic waters. Environmental Microbiology 15: 3054-3064.

Gundersen, K., Heldal, M., Norland, S., Purdie, D.A., and Knap, A.H. (2002) Elemental C, N, and $\mathrm{P}$ cell content of individual bacteria collected at the Bermuda Atlantic Time-Series Study (BATS) Site. Limnology and Oceanography 47: 1525-1530.

Jochem, F.J., Lavrentyev, P.J., and First, M.R. (2004) Growth and grazing rates of bacteria groups with different apparent DNA content in the Gulf of Mexico. Marine Biology 145: 12131225 .

Johnson, D.L. (1971) Simultaneous Determination of Arsenate and Phosphate in Natural Waters. Environmental Science \& Technology 8: 411-414.

Karl, D.M. (1981) Simultaneous rates of ribonucleic acid and deoxyribonucleic acid syntheses for estimating growth and cell division of aquatic microbial communities. Applied and Environmental Microbiology 42: 802-810.

Karl, D.M. (2014) Microbially mediated transformations of phosphorus in the sea: new views of an old cycle. Annual Review of Marine Science 6: 279-337. 
Karl, D.M., and Bossard, P. (1985) Measurement and significance of ATP and adenine nucleotide pool turnover in microbial cells and environmental samples. Journal of Microbiological Methods 3: 125-139.

Karl, D.M., and Tien, G. (1992) MAGIC: A sensitive and precise method for measuring dissolved phosphorus in aquatic environments. Limnology and Oceanography 37: 105-116.

Karl, D.M., and Björkman, K. (2015) Dynamics of DOP. In Biogeochemistry of Marine Dissolved Organic Matter. Hansell, D.A., and Carlson, C.A. (eds): Academic Press, pp. 233-334.

Kemp, P.F., Lee, S., and LaRoche, J. (1993) Estimating the growth rate of slowly growing marine bacteria from RNA content. Applied and Environmental Microbiology 59: 2594-2601.

Kerkhof, L., and Ward, B.B. (1993) Comparison of nucleic acid hybridization and fluorometry for measurement of the relationship between RNA/DNA ratio and growth rate in marine bacterium. Applied and Environmental Microbiology 59: 1303-1309.

Kolowith, L.C., Ingall, E.D., and Benner, R. (2001) Composition and cycling of marine organic phosphorus. Limnology and Oceanography 46: 309-320.

Krom, M.D., Kress, N., Brenner, S., and Gordon, L.I. (1991) Phosphorus limitation of primary production in the eastern Mediterranean Sea. Limnology and Oceanography 36: 424-432.

Kujawinski, E.B. (2011) The impact of microbial metabolism on marine dissolved organic matter. Annual Review of Marine Science 3: 567-599.

Lebaron, P., Servais, P., Agogué, H., Courties, C., and Joux, F. (2001) Does the high nucleic acid content of individual bacterial cells allow us to discriminate between active and inactive cells in aquatic systems? Applied and Environmental Microbiology 67: 1775-1782.

Lebaron, P., Servais, P., Baudoux, A.-C., Bourrain, M., Courties, C., and Parthuisot, N. (2002) Variations of bacterial-specific activity with cell size and nucleic acid content assessed by flow cytometry. Aquatic Microbial Ecology 28: 131-140.

Li, H., Veldhuis, M.J.W., and Post, A.F. (1998) Alkaline phosphatase activities among planktonic communities in the northern Red Sea. Marine Ecology Press Series 173: 107-115.

Li, W.K.W. (1994) Primary production of prochlorophytes, cyanobacteria, and eucaryotic ultraphytoplankton: Measurements from flow cytometric sorting. Limnology and Oceanography 39: 169-175.

Li, W.K.W., Subba Rao, D.V., Harrison, W.G., Smith, J.C., Cullen, J.J., Irwin, B., and Platt, T. (1983) Autotrophic picoplankton in the tropical ocean. Science 219: 292-295.

Lomas, M.W., Bonachela, J.A., Levin, S.A., Martiny, A.C. (2014) Impact of ocean phytoplankton diversity on phosphate uptake. Proceedings of the National Academy of Sciences 111: 17540-17545. 
Lomas, M.W., Bronk, D.A., and van den Engh, G. (2011) Use of flow cytometry to measure biogeochemical rates and processes in the ocean. Annual Review of Marine Science 3: 537-566.

Lomas, M.W., Burke, A.L., Lomas, D.A., Bell, D.W., Shen, C., Dyhrman, S.T., and Ammerman, J.W. (2010) Sargasso Sea phosphorus biogeochemistry: an important role for dissolved organic phosphorus (DOP). Biogeosciences 7: 695-710.

Malfatti, F., and Azam, F. (2009) Atomic force microscopy reveals microscale networks and possible symbioses among pelagic marine bacteria. Aquatic Microbial Ecology 58: 1-14.

Martin, P., and Van Mooy, B.A.S. (2013) Fluorometric quantification of polyphosphate in environmental plankton samples: extration protocols, matrix effects, and nucleic acid interference. Applied and Environmental Microbiology 79: 273-281.

Martiny, A.C., Huang, Y., and Li, W. (2009) Occurence of phosphate acquisition genes in Prochlorococcus cells from different ocean regions. Environmental Microbiology 11: 1340-1347.

Mather, R.L., Reynolds, S.E., Wolff, G.A., Williams, R.G., Torres-Valdes, S., Woodward, E.M.S. et al. (2008) Phosphorus cycling in the North and South Atlantic Ocean subtropical gyres. Nature Geosciences 1: 439-443.

Michelou, V.K., Lomas, M.W., and Kirchman, D.L. (2011) Phosphate and adenosine-5'triphosphate uptake by cyanobacteria and heterotrophic bacteria in the Sargasso Sea. Limnology and Oceanography 56: 323-332.

Moutin, T., Van Den Broeck, N., Beker, B., Dupouy, C., Rimmelin, P., and Le Bouteiller, A. (2005) Phosphate availability controls Trichodesmium spp. biomass in the SW Pacific Ocean. Marine Ecology Press Series 297: 15-21.

Oliver, J.D., and Colwell, R.R. (1973) Extractable Lipids of Gram-Negative Marine Bacteria: Phospholipid Composition. Journal of Bacteriology 114: 897-908.

Partensky, F., Hess, W.R., and Vaulot, D. (1999) Prochlorococcus, a marine photosynthetic prokaryote of global significance. Microbiology and Molecular Biology Reviews 63: 106-127.

Perry, M.J. (1976) Phosphate utilization by an oceanic diatom in phosphorus-limited chemostate cultures and in oligotrophic waters of the central North Pacific. Limnology and Oceanography 21: $88-107$.

Pomeroy, L.R., Sheldon, J.E., Sheldon Jr, W.M., and Peters, F. (1995) Limits to growth and respiration of bacterioplankton in the Gulf of Mexico. Marine Ecology Press Series 117: 259268.

Popendorf, K.J., Lomas, M.W., and Van Mooy, B.A.S. (2011a) Microbial sources of intact polar diacylglycerolipids in the Western North Atlantic Ocean. Organic Geochemistry 42: 803-811. 
Popendorf, K.J., Fredricks, H.F., and Van Mooy, B.A.S. (2013) Molecular ion-independent quantification of polar glycerolipid classes in marine plankton using triple quadrupole MS.

Lipids 48: 185-195.

Popendorf, K.J., Tanaka, T., Pujo-Pay, M., Lagaria, A., Courties, C., Conan, P. et al. (2011b) Gradients in intact polar diacylglycerolipids across the Mediterranean Sea are related to phosphate availability. Biogeosciences 8: 3733-3745.

Rappé, M.S., Connon, S.A., Vergin, K.L., and Giovannoni, S.J. (2002) Cultivation of the ubiquitous SAR11 marine bacterioplankton clade. Nature 418: 630-633.

Raven, J.A. (1998) The twelth Tansley lecture. Small is beautiful: the picophytoplankton.

Functional Ecology 12: 503-513.

Strickland, and Parsons (1972) A Practical Handbook of Seawater Analysis.

Talarmin, A., Van Wambeke, F., Lebaron, P., and Moutin, T. (2014) Vertical partitioning of phosphate uptake among picoplankton groups in the P-depleted Mediterranean Sea.

Biogeosciences Discussion 11: 14639-14665.

Thingstad, T.F., Krom, M.D., Mantoura, R.F.C., Flaten, G.A.F., Groom, S., Herut, B. et al. (2005) Nature of phosphorus limitation in the ultraoligotrophic eastern Mediterranean. Science 309: 1068-1071.

Thomson-Bulldis, A.L., and Karl, D.M. (1998) Application of a novel method for phosphorus determinations in the oligotrophic North Pacific Ocean. Limnology and Oceanography 43: 15651577.

Turner, R.E., and Rabalais, N.N. (2013) Nitrogen and phosphorus phytoplankton growth limitation in the northern Gulf of Mexico. Aquatic Microbial Ecology 68: 159-169.

Van Mooy, B.A.S., and Devol, A.H. (2008) Assessing nutrient limitation of Prochlorococcus in the North Pacific subtropical gyre by using an RNA capture method. Limnology and Oceanography 53: 78-88.

Van Mooy, B.A.S., and Fredricks, H.F. (2010) Bacterial and eukaryotic intact polar lipids in the eastern subtropical South Pacific: Water-column distribution, planktonic sources, and fatty acid composition. Geochimica et Cosmochimica Acta 74: 6499-6516.

Van Mooy, B.A.S., Rocap, G., Fredricks, H.F., Evans, C.T., and Devol, A.H. (2006) Sulfolipids dramatically decrease phosphorus demand by picocyanobacteria in oligotrophic environments. Proceedings of the National Academy of Sciences 103: 8607-8612.

Van Mooy, B.A.S., Hmelo, L.R., Fredricks, H.F., Ossolinski, J.E., Pedler, B.E., Bogorff, D.J., and Smith, P.J.S. (2014) Quantitative exploration of the contribution of settlement, growth, dispersal and grazing to the accumulation of natural marine biofilms on antifouling and foulingrelease coatings. Biofouling 30: 223-236. 
Van Mooy, B.A.S., Fredricks, H.F., Pedler, B.E., Dyhrman, S.T., Karl, D.M., Koblízek, M. et al. (2009) Phytoplankton in the ocean substitute phospholipids in response to phosphorus scarcity.

Nature 458: 69-72.

Wada, H., and Murata, N. (1998) Membrane Lipids in Cyanobacteria. In Lipids in

Photosynthesis: Structure, Function and Genetics. Siegenthaler, P.-A., and Murata, N. (eds).

Netherlands: Kluwer Academic Publishers, pp. 65-81.

Wakeham, S.G., Hedges, J.I., Lee, C., Peterson, M.L., and Hernes, P.J. (1997) Compositions and transport of lipid biomarkers through the water column surficial sediments of the equatorial Pacific Ocean. Deep-Sea Research II 44: 2131-2162.

White, A.E., Watkins-Brandt, K.S., Engle, M.A., Burkhardt, B., and Paytan, A. (2012) Characterization of the rate and temperature sensitivities of bacterial remineralization of dissolved organic phosphorus compounds by natural populations. Frontiers in Microbiology 3: $1-13$.

Young, C.L., and Ingall, E.D. (2010) Marine dissolved organic phosphorus composition: insights from samples recovered using combined electrodialysis/reverse osmosis. Aquatic Geochemistry 16: $563: 574$.

Zhang, Y.-M., and Rock, C. O. (2008) Membrane lipid homeostatis in bacteria. Nature Reviews Microbiology 6: 222-233.

Zimmerman, A.E., Allison, S.D., and Martiny, A.C. (2014a) Phylogenetic constraints on elemental stoichiometry and resource allocation in heterotrophic marine bacteria. Environmental Microbiology 16: 1398-1410.

Zimmerman, A.E., Martiny, A.C., Lomas, M.W., and Allison, S.D. (2014b) Phosphate supply explains variation in nucleic acid allocation but not C:P stoichiometry in the western North Atlantic. Biogeosciences 11: 1599-1611.

Zubkov, M.V., Fuchs, B.M., Burkill, P.H., and Amann, R. (2001) Comparison of cellular and biomass specific activities of dominant bacterioplankton groups in stratified waters of the Celtic Sea. Applied and Environmental Microbiology 67: 5210-5218.

Zubkov, M.V., Fuchs, B.M., Eilers, H., Burkill, P.H., and Amann, R. (1999) Determination of total protein content of bacterial cells by SYPRO staining and flow cytometry. Applied and Environmental Microbiology 65: 3251-3257.

Zubkov, M.V., Mary, I., Woodward, E.M.S., Warwick, P.E., Fuchs, B.M., Scanlan, D.J., and Burkill, P.H. (2007) Microbial control of phosphate in the nutrient-depleted North Atlantic subtropical gyre. Environmental Microbiology 9: 2079-2089.

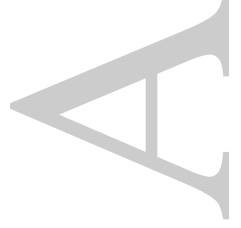




\section{Table and Figure Legends}

\section{Table 1}

Station locations in the Northern Gulf of Mexico, including sample depths, water column properties at those depths, and dissolved phosphorus concentrations (average \pm standard deviation of replicate samples).

\section{Table 2}

Cell abundance, phosphorus uptake rate (per cell and per biovolume), and phosphorus allocation to phospholipid production for Prochlorococcus, Synechococcus, eukaryotic phytoplankton, and heterotrophic bacteria. Data are presented as average and standard deviation of samples at each station (St 1, 2, and 3) as well average and standard deviation of all samples combined (Ave all $\mathrm{St})$.

\section{Figure 1}

Concentrations of dissolved inorganic phosphorus (DIP) and dissolved organic phosphorus (DOP) at three stations (shown in different shades of grey) in the northern Gulf of Mexico, sampled at both $10 \mathrm{~m}$ and the deep chlorophyll maximum (DCM; 50-60 m depth).

Representative profiles of temperature, salinity, and fluorescence for the upper $100 \mathrm{~m}$ at Station

2. Arrows indicate the depths of samples for dissolved P concentration.

\section{Figure 2}

Cell abundances and dissolved $\mathrm{P}$ uptake rates of the four dominant picoplankton groups in the Gulf of Mexico, non-pigmented heterotrophic bacteria (bac) in black, Prochlorococcus (Pro) in 
dark grey, Synechococcus (Syn) in light grey, eukaryotic phytoplankton (euk) in white. Each bar shows averages of samples drawn from three stations; error bars are one standard deviation. Cell abundance $\left(10^{5}\right.$ cells $\left.\mathrm{mL}^{-1)}\right)$ at two depths, $10 \mathrm{~m}$ (panel A) and the DCM (panel B). Uptake rates of DIP (solid bars in panels C through F) and adenosine triphosphate (ATP; dotted bars in panels $\mathrm{C}$ through $\mathrm{F}$ ) in each microbial group, shown as uptake rate per biomass volume (amol $\mathrm{P} \mu \mathrm{m}^{-3} \mathrm{hr}^{-}$ ${ }^{1}$; panels C, D) and uptake rate per cell (amol $\mathrm{P} \mathrm{cell}^{-1} \mathrm{hr}^{-1}$; panels E, F). In each panel, identical lowercase letters to the right of the panel indicate data that were not statistically different in post hoc comparisons (for panels $\mathrm{C}$ through F posthoc comparisons were done separately for DIP and ATP, italics indicate statistical significance of ATP data).

\section{Figure 3}

DIP (panels A and C) and ATP (panels B and D) uptake rate per microbial group (pmol P L ${ }^{-1} \mathrm{hr}^{-}$ $\left.{ }^{1}\right)$ for bac in black, Pro in dark grey, Syn in light grey, and euk in white. Stacked bar represents total picoplankton P uptake at $10 \mathrm{~m}$ (panels $\mathrm{A}$ and $\mathrm{B}$ ) and the DCM (panels $\mathrm{C}$ and $\mathrm{D}$ ). (1)

\section{Figure 4}

Phosphorus (P) allocation into phospholipids as a fraction of DIP uptake (panel A) and ATP uptake (panel B) in bac (black), Pro (dark grey), and Syn (light grey). Solid color portion of bars show phosphorus allocation into phosphatidylglycerol (PG), dotted portion of bars show allocation into phosphatidylethanolamine (PE), and cross-hatched portion of bars show allocation into phosphatidylcholine (PC). P allocation into phospholipids is plotted against the expected surface area to volume ratio (panel C) for all data points (DIP and ATP allocation) in each microbial group (Syn $\mathrm{n}=7$, Pro $\mathrm{n}=5$, bac $\mathrm{n}=6$ ). The ratio of $\mathrm{P}$ allocation to surface 
area/volume is plotted for each microbial group (panel D), with filled diamonds showing the average value, bars showing standard error, and open diamonds showing the range.

\section{Figure 5}

Phosphorus (P) uptake in each microbial group as a percentage of total picoplankton community P uptake is plotted versus (A) cell abundance as a percentage of total picoplankton cell abundance, and (B) biomass volume as a percentage of total picoplankton biomass for all samples (both DIP and ATP uptake at $10 \mathrm{~m}$ and the DCM). Bac represented by black filled circles, Pro by dark grey filled diamonds, Syn by light grey filled squares, and euk by white open triangles. Linear fit, forced through the origin, and correlation coefficients are given for each microbial group.

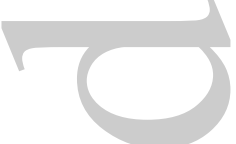

\section{Figure 6}

Ratio of average DIP uptake rate (amol P cell ${ }^{-1} \mathrm{hr}^{-1}$ ) to average DOP uptake rate (amol P cell-1 $\mathrm{hr}^{-}$ ) for each microbial group, at $10 \mathrm{~m}$ (panel A) and the DCM (panel B). 


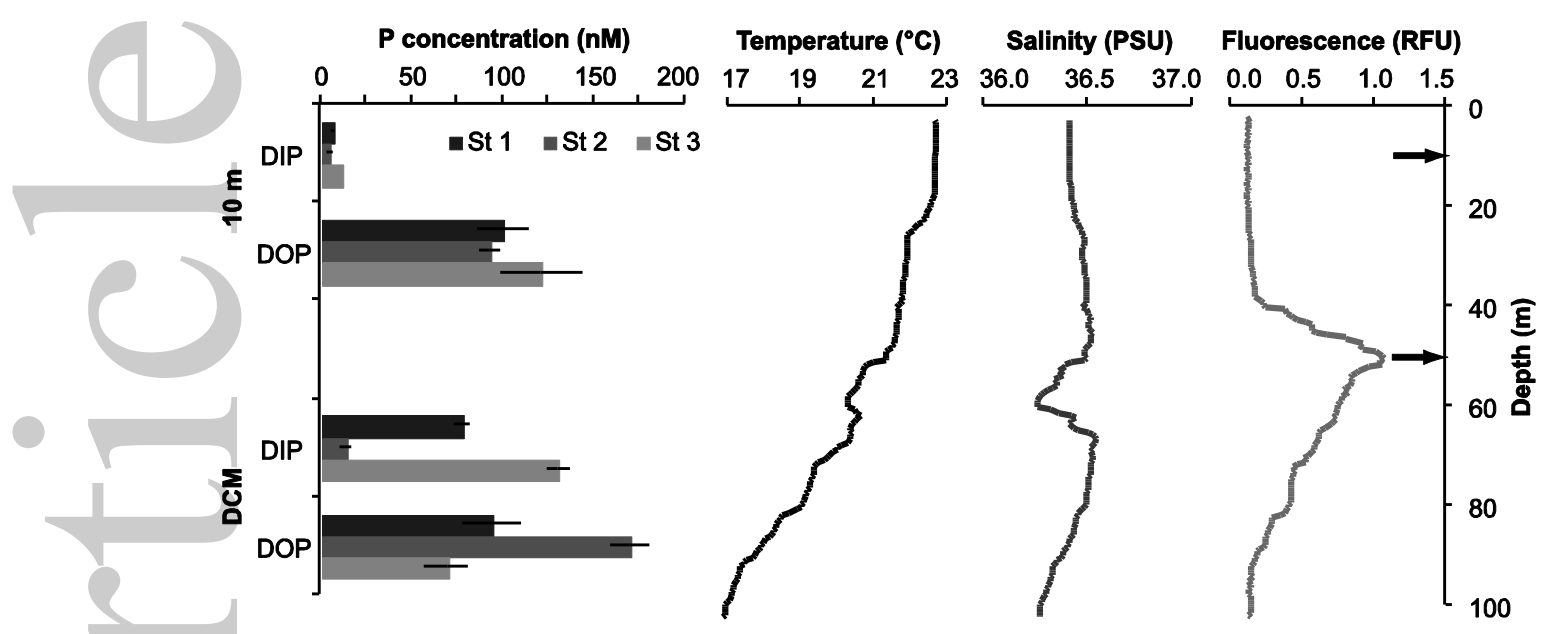

EMI_12932_F1

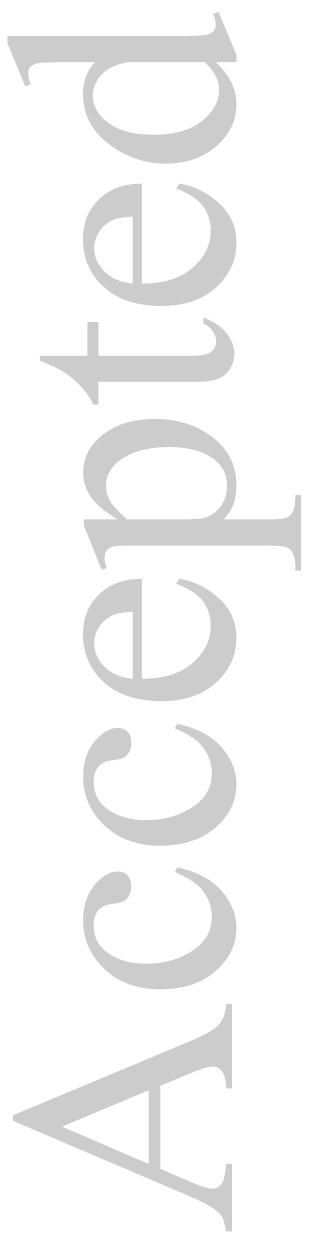

This article is protected by copyright. All rights reserved. 

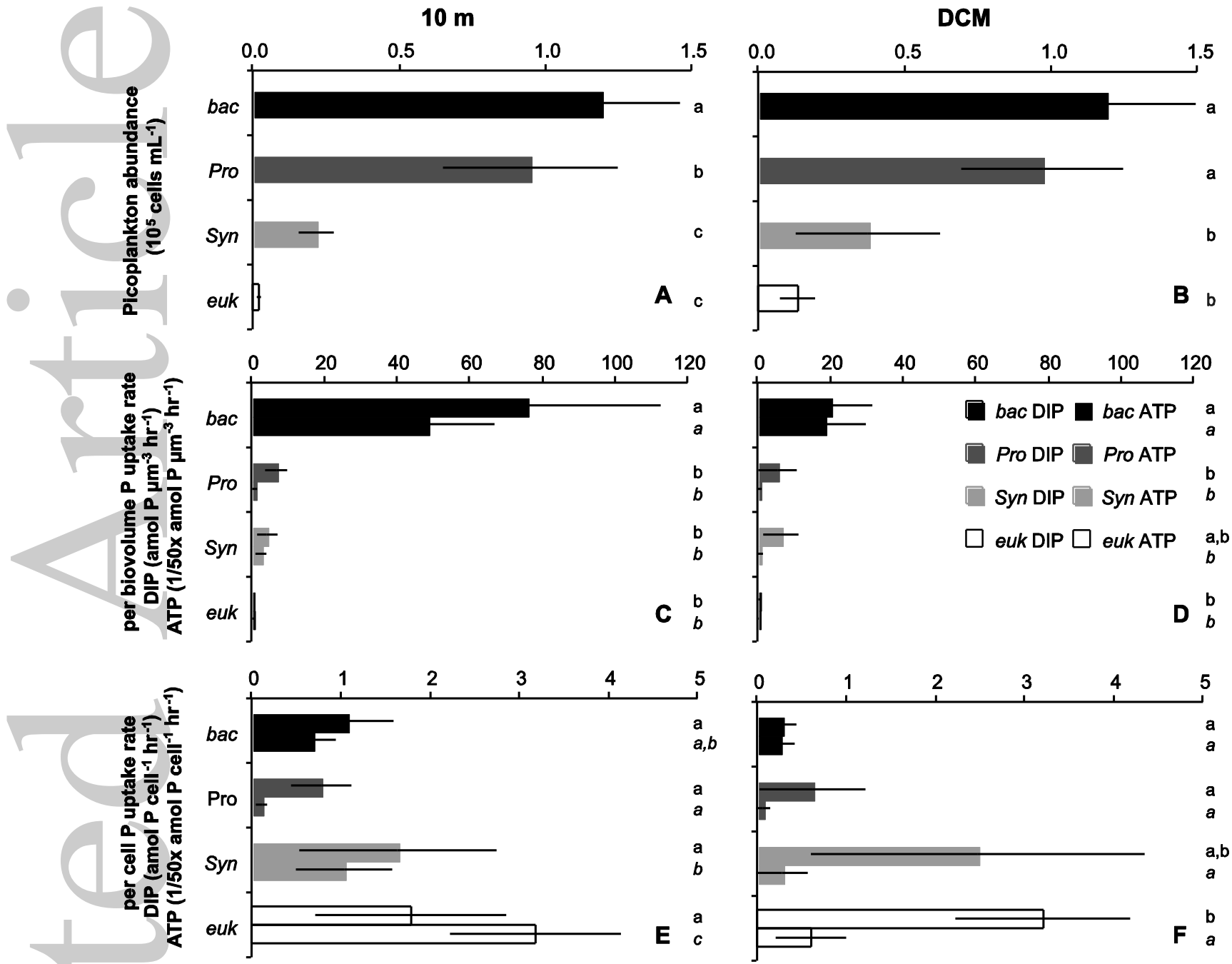

EMI_12932_F2 

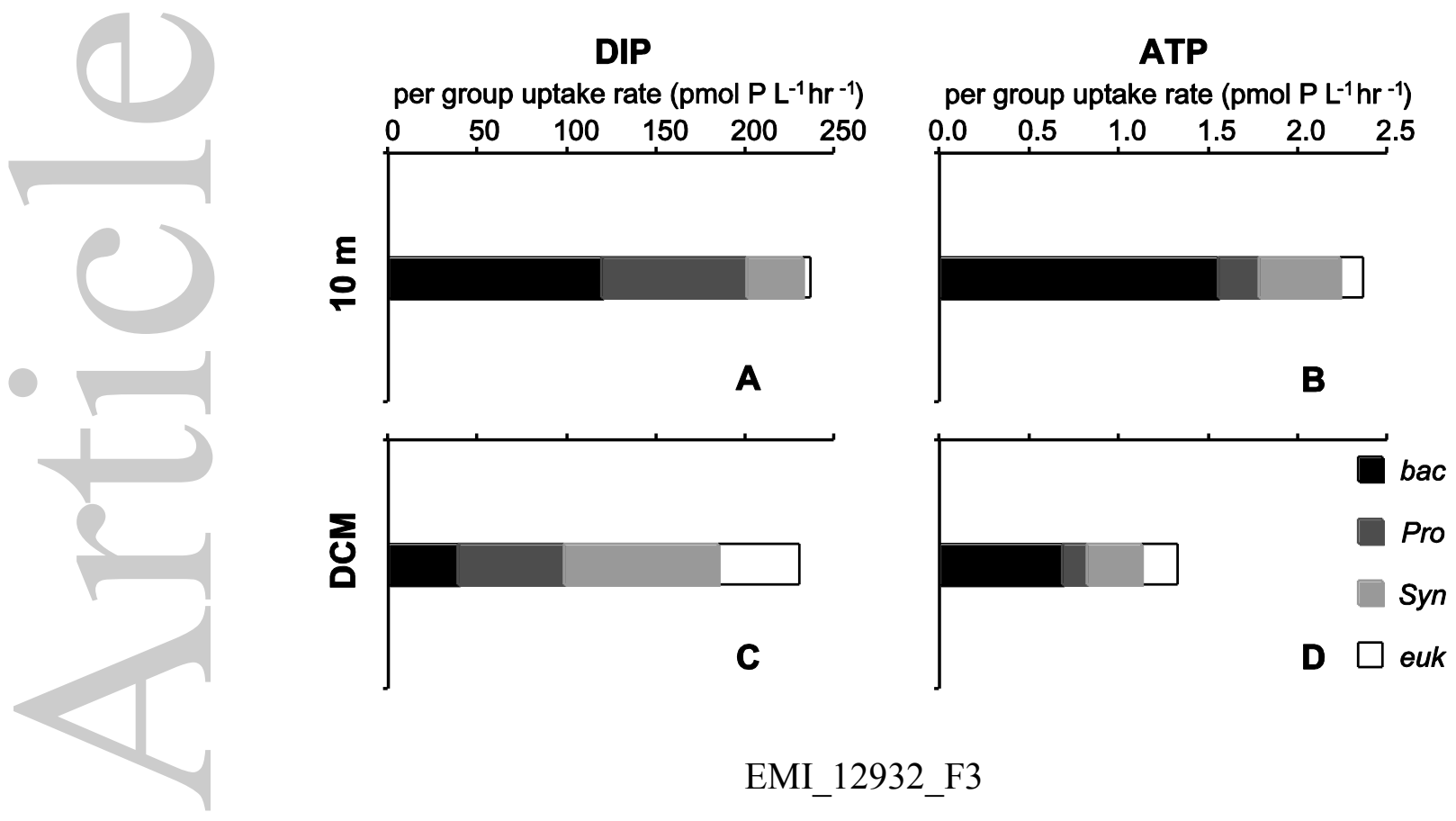

EMI_12932_F3

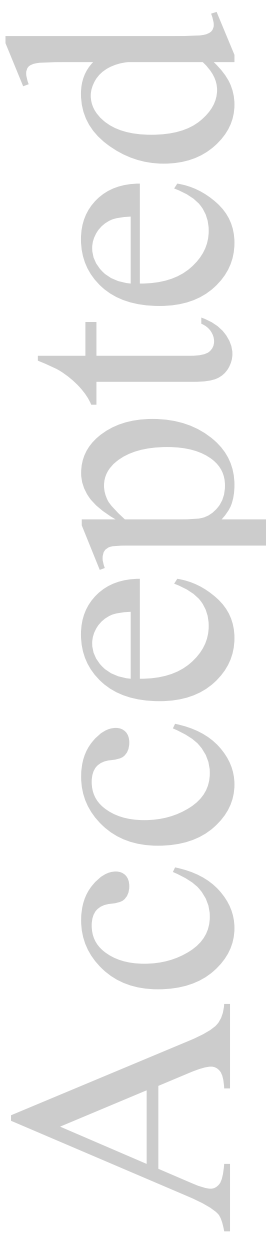



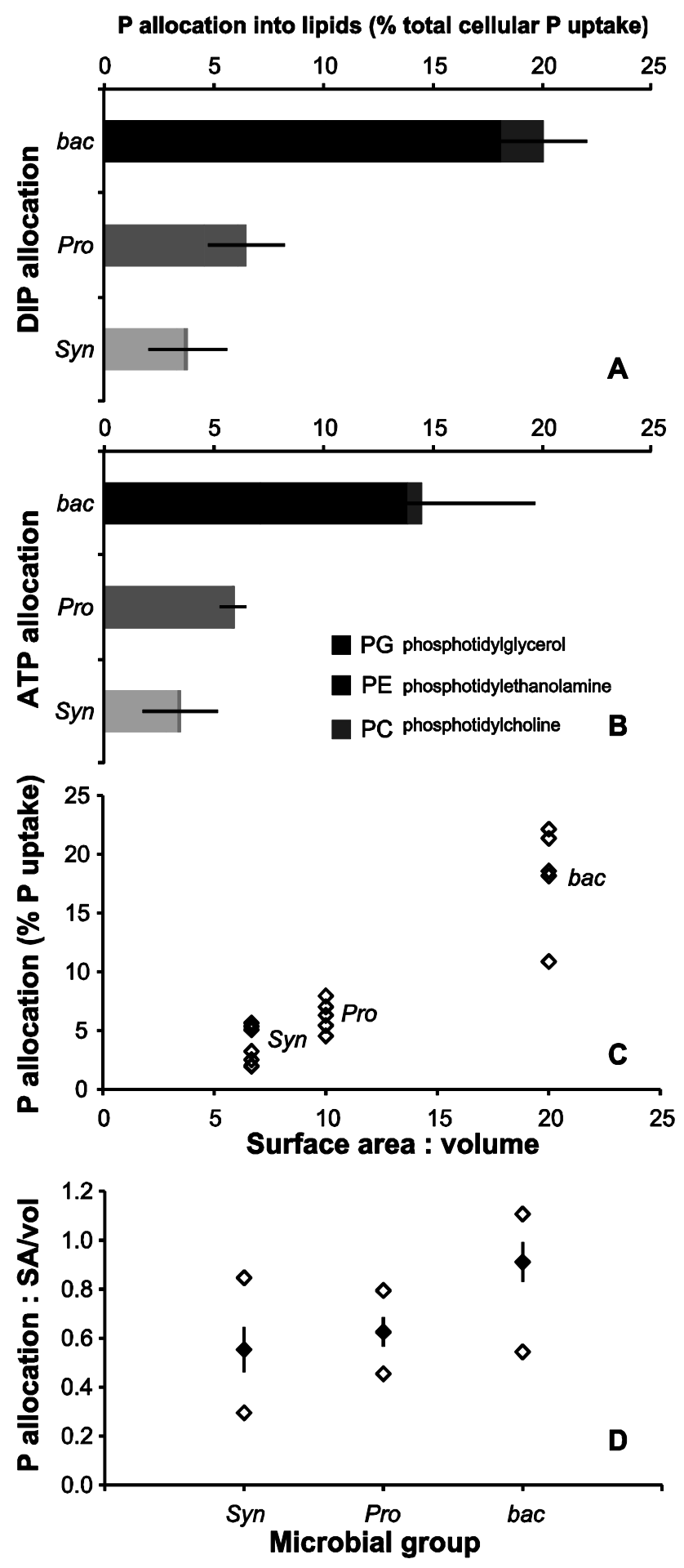

EMI_12932_F4 

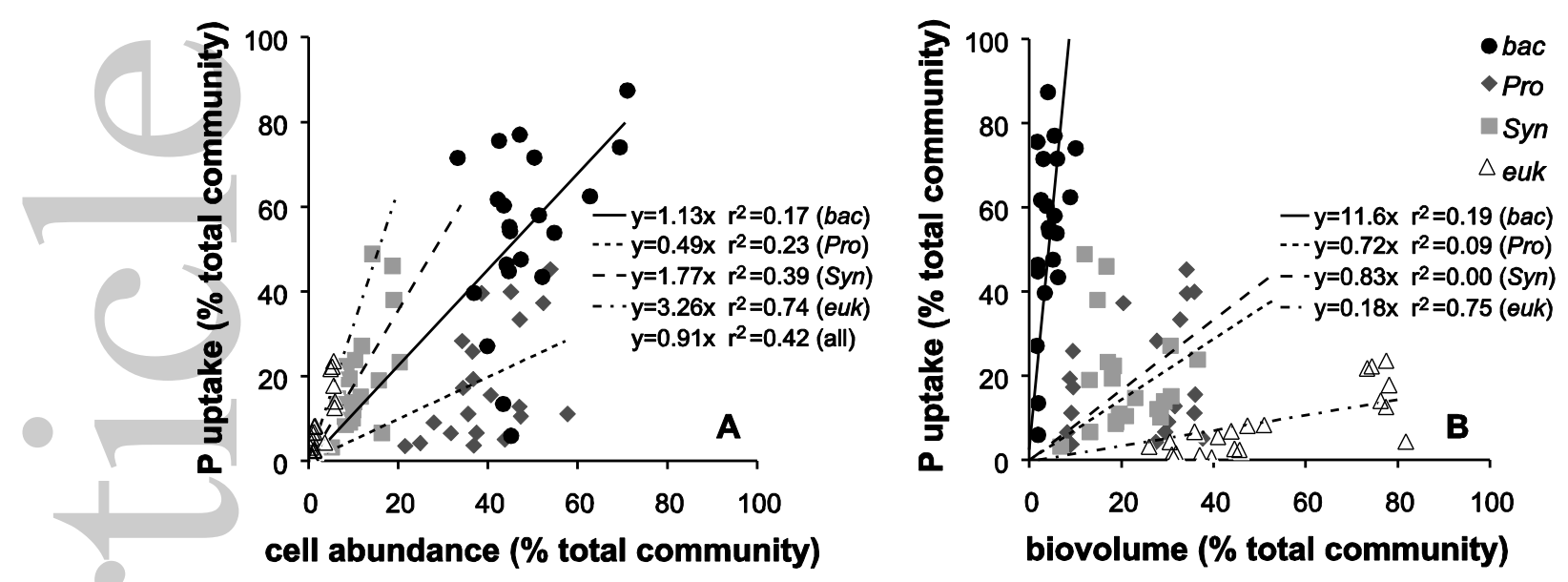

EMI_12932_F5 

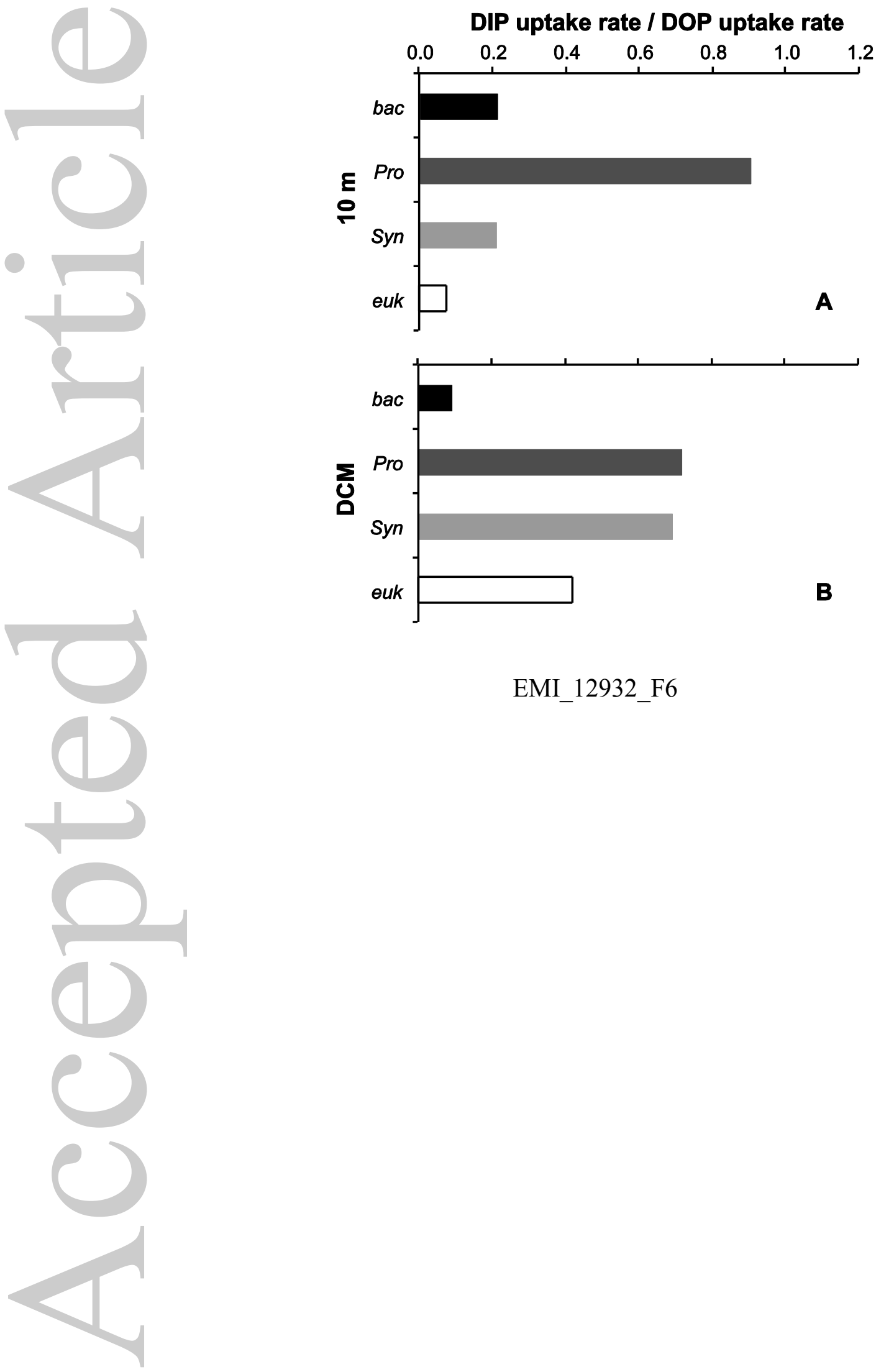

EMI_12932_F6 
Table 1

\begin{tabular}{|c|c|c|c|c|c|c|c|c|c|}
\hline & $\begin{array}{l}\text { Lat } \\
{ }^{\circ} \mathrm{N}\end{array}$ & $\begin{array}{l}\text { Long } \\
{ }^{\circ} \mathrm{W} \\
\end{array}$ & $\begin{array}{c}\text { sampling } \\
\text { date }\end{array}$ & $\begin{array}{c}\text { MLD } \\
\mathrm{m}\end{array}$ & $\begin{array}{c}\text { sample depth } \\
\mathrm{m}\end{array}$ & $\begin{array}{c}\mathrm{T} \\
{ }^{\circ} \mathrm{C} \\
\end{array}$ & $\begin{array}{c}\mathrm{S} \\
\mathrm{PSU} \\
\end{array}$ & $\begin{array}{l}\mathrm{SRP} \\
\mathrm{nM}\end{array}$ & $\begin{array}{c}\mathrm{DOP} \\
\mathrm{nM}\end{array}$ \\
\hline \multirow{2}{*}{ Station 1} & \multirow{2}{*}{$29.0101 \mathrm{~N}$} & \multirow{2}{*}{$87.9927 \mathrm{~W}$} & \multirow{2}{*}{$4 / 15 / 2013$} & \multirow{2}{*}{34} & 10 & 23.6 & 36.3 & $7.4 \pm 1.0$ & $100.7 \pm 14.2$ \\
\hline & & & & & $52(\mathrm{DCM})$ & 22.7 & 36.7 & $78.3 \pm 4.2$ & $94.3 \pm 16.7$ \\
\hline \multirow{2}{*}{ Station 2} & \multirow{2}{*}{$28.5231 \mathrm{~N}$} & \multirow{2}{*}{$88.5958 \mathrm{~W}$} & \multirow{2}{*}{$4 / 12 / 2013$} & \multirow{2}{*}{23} & 10 & 22.7 & 36.4 & $5.6 \pm 1.9$ & $93.0 \pm 6.3$ \\
\hline & & & & & $50(\mathrm{DCM})$ & 21.4 & 36.5 & $14.2 \pm 3.3$ & $170.0 \pm 11.3$ \\
\hline \multirow{2}{*}{ Station 3} & \multirow{2}{*}{$28.5075 \mathrm{~N}$} & \multirow{2}{*}{$88.0286 \mathrm{~W}$} & \multirow{2}{*}{ 4/6/2013 } & \multirow{2}{*}{40} & 10 & 22.1 & 36.5 & $12.5 \pm 0.0$ & $121.7 \pm 22.8$ \\
\hline & & & & & 60 (DCM) & 20.9 & 36.5 & $130.7 \pm 6.6$ & $69.6 \pm 13.4$ \\
\hline
\end{tabular}

$\mathrm{MLD}=$ mixed layer depth, $\mathrm{DCM}=$ deep chlorophyll maximum, $\mathrm{T}=$ temperature, $\mathrm{S}=$ salinity,

$\mathrm{SRP}=$ soluble reactive phosphorus, $\mathrm{DOP}=$ dissolved organic phosphorus 


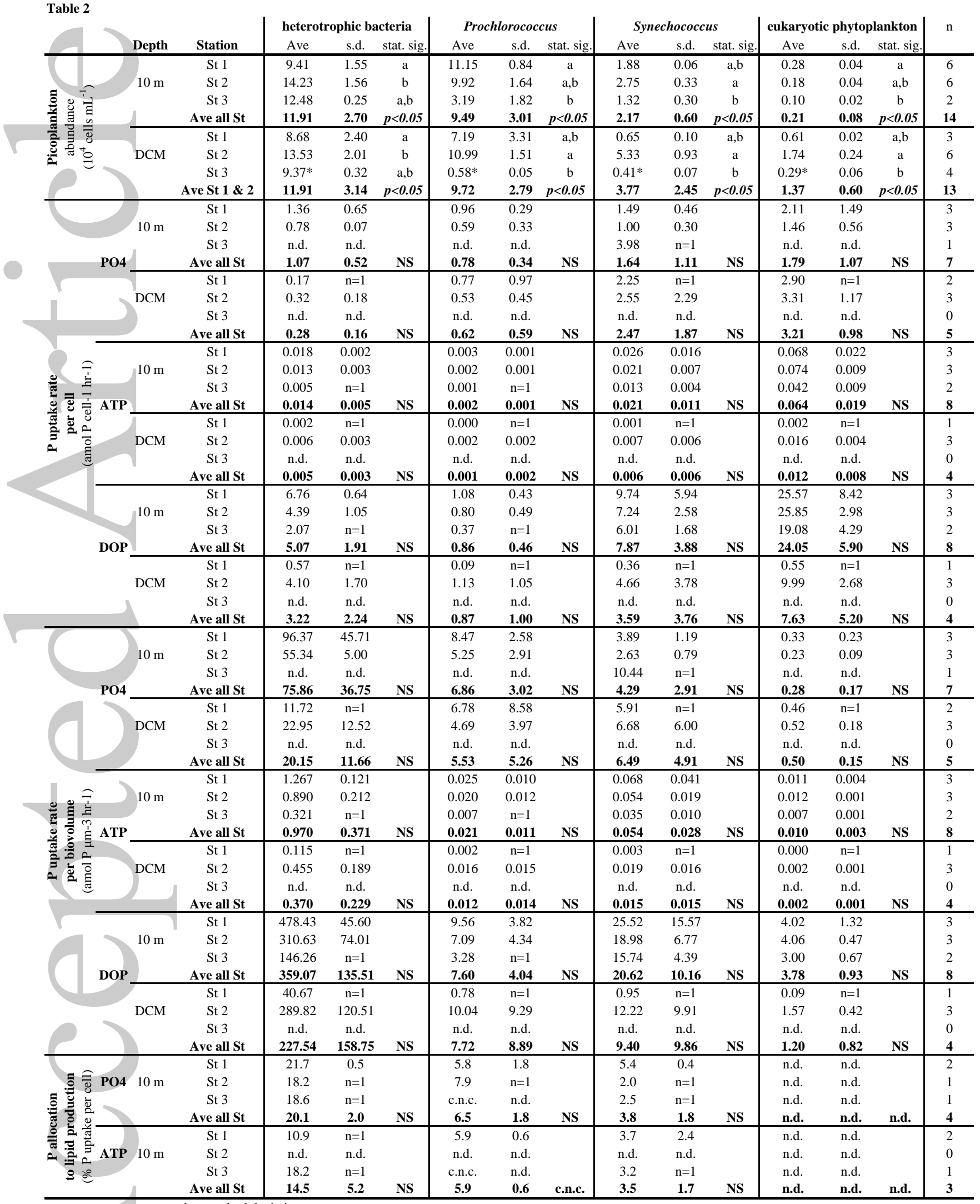

s.d.= standard deviation

stat. sig.= test for statistical difference between stations using Kruskal-Wallis and post-hoc bonferroni, in Matlab v. R2012a. $\mathrm{n}=$ number of samples

n.d.= no data

c.n.c. $=$ can not calculate (one or more pieces of necessary data not measured)

$p<0.05=$ parameters with station average values that are statistically significantly different, stations with the same letter are not statistically different in post-hoc test. $\mathrm{NS}=$ no statistically significant difference between stations

*= average of stations calculated for those samples where parallel P uptake measurements were available, this excludes St 3 DCM cell counts 